\title{
Seed Production and Seed Sources of Organic Vegetables ${ }^{1}$
}

Jennifer Bonina and Daniel J. Cantliffe ${ }^{2}$

\section{The Demand for Organic Vegetables and Seed}

The organic vegetable industry is flourishing due to consumers preference for organically grown produce over traditionally produced vegetables. As a result, an increase in the variety and selection of many vegetables in retail supermarkets and restaurants throughout the United States has occurred recently. With the new regulation (October 2000) requiring organic seed sources for organically labeled vegetables, many organic growers are searching for certified organic seed. Smaller seed companies have produced the majority of organically produced seed to date. The commercial seed sector is starting to provide a more diverse selection of cultivars, yet there are still many hybrids that are not yet available. For growers in Florida, there is opportunity to produce organic, though it is not widely practiced. This report serves as a guide to organic seed production in Florida.

\section{U.S. Seed Production}

Commercial vegetable seed production in the United States occurs mainly on the west coast in
Oregon, Washington, Idaho, and California. The weather conditions in these areas have low humidity, excellent soils, and a warm, sunny, dry climate during summer which is favorable for organic seed production. These environmental conditions allow for a lower incidence of disease pest problems and a longer growing season, which are necessary for high quality seed production.

The Northeast and Midwest have also produced vegetable seeds in the past but now with the demand for organic seed increasing, seed producers in these regions have begun producing organic seed. These areas can be successful for producing seeds of many crops, even though the climate does not permit an extended growing season.

Selection of a seed crop that will thrive in the environmental conditions of the selected area is critical for achieving economic profit for the seed produced. Though Florida is not presently a prime area for seed production, okra, sweet corn, field corn, watermelon, and some other cucurbits were produced using traditional methods in the past (Hawthorn et al,1954). Commercial peanut seed production also continues to thrive in Florida. There are areas of

1. This document is HS981, one of a series of the Department of Horticultural Sciences, Florida Cooperative Extension Service, Institute of Food and Agricultural Sciences, University of Florida. Original publication date: July 2004. Please visit the EDIS Web site at http://edis.ifas.ufl.edu.

2. Jennifer Bonina, graduate assistant, and Daniel J. Cantliffe, professor, Horticultural Sciences Department, Cooperative Extension Service, Institute of Food and Agricultural Sciences, University of Florida, Gainesville, FL 32611.

The Institute of Food and Agricultural Sciences (IFAS) is an Equal Employment Opportunity - Affirmative Action Employer authorized to provide research, educational information and other services only to individuals and institutions that function without regard to race, creed, color, religion, age, disability, sex, sexual orientation, marital status, national origin, political opinions or affiliations. For information on obtaining other extension publications, contact your county Cooperative Extension Service office. Florida Cooperative Extension Service / Institute of Food and Agricultural Sciences / University of Florida / Larry R. Arrington, Interim Dean 
Florida that have the potential to produce organic vegetable seeds, such as watermelon, muskmelon, and other cucurbits. Conditions in Florida are not conducive for growing longer season crops such as lettuce and carrots due to prolonged high temperatures and other environmental conditions.

Many organic growers want to grow open-pollinated as well as hybrid cultivars. To be considered a hybrid, the seed must be the offspring of two parents that differ in one or more heritable characteristics. For example, a green bean cultivar that has excellent flavor but is susceptible to a certain pest crossed with a different cultivar that is tolerant of the same pest, the two cultivars could be crossed and the new hybrid might have both excellent flavor and be resistant to the pest, provided the parents are homozygous. Seeds collected from a grown hybrid cultivar will not be true to type when replanted and thus can not be saved to plant next years crop (Kirschenbaum, 2000).

One of the alternatives to hybrids is open-pollinated cultivars. These are produced by selfing or outcrossing to the same parental type. Other open-pollinated cultivars are referred to as heirloom cultivars because they have been grown for many decades. There is no standard length of time that a cultivar has to be grown in order to be considered an heirloom cultivar but generally 40 years is minimum (Kirschenbaum, 2000). Since hybrid production requires obtaining the two inbred parents for crossing, they are mostly produced by commercial seed companies who own or develop the parental stocks. Thus, for smaller commercial seed companies and producers who grow their own organic seeds, only open pollinated cultivars are produced.

\section{Conventional vs. Organic Seed Production}

Vegetable crops are produced for two distinct markets, fresh and processed. Conventional cultural practices are fairly similar. Growing crops for seed requires a longer season since the crop must stay in the field twice as long as a conventional crop harvested for fruit and also for increased monitoring to ensure high seed quality and purity.
Standard production of vegetable seeds requires chemical herbicides, insecticides, fungicides, and fertilizers. An increase in the amount of chemical products used on seed crops may occur due to the length of time the crops remain in the field. As a result, plant diseases and insects have more time to attack the crop during seed maturation (George, 1993). With these factors playing a role in conventional seed production, the challenges for organic seed production are increased.

\section{The USDA Guidelines for Organic Produce and Seeds}

Organic farming practices began on small farms in the United States during the 1940s. As the diversity of crops labeled organic increased, there became a need for certification standards and regulations to ensure proper guidelines for growing organic crops. By the 1980s, the organic industry increased dramatically, resulting in the establishment of the Organic Certification Board which issued the Organic Foods Production Act (OFPA), identifying "organic" produce. New laws now stipulate that as of October 2002, all producers and handlers must be certified by a USDA certification agent to label or sell a crop as "organically grown." The new regulations also include new standards for seed sources when producing organic crops:

\subsection{The producer must use organically} grown seeds, annual seedlings, and planting stock, Except, That, (1) Nonorganically produced, untreated seeds and planting stock may be used to produce an organic crop when an equivalent organically produced variety is not commercially available, Except, That, organically produced seed must be used for the production of edible sprouts.

Though the guidelines do not require that all seeds be organically produced, at present, if seeds are not available by January, 2004, a new regulation will require producers of organic crops to use organically produced seeds for all crops:

\subsubsection{Recommended Practices: Organically} produced seeds, seedlings, scions and rootstocks; Other forms of non-toxic seed treatments, such as hot water, legume inoculants, pelletization (when not involving fungicides); Assorted plant and/or animal 
preparations, biodynamic preparations, microbial activators, bacterial inoculants, and mycorhizea, etc. All products must be naturally occurring (not the result of genetic engineering); 5.3.2 Restricted Practices Untreated conventionally produced seed may be used if organically produced seed is unavailable until 2003. Thereafter, organically produced seed must be used.; The extent to which producers rely on non- plant materials should be clearly documented.

\section{Guidelines for Organic Seed Production}

\section{Land Selection}

Good farming practices are especially important when growing vegetable crops for seed. Proper selection of land is critical to ensure maximum quality and economic yield. Crops should be rotated to reduce pest problems and any potential for seed contamination by open pollination with similar species types.

The seed production field should not have known weed problems that are too difficult to control through organic means as weeds will compete significantly with the crop, resulting in seed yield and purity problems. Weed management is a major problem with organic crop production.

\section{Land Preparation and Soil Fertilization}

Soil should be tilled to ensure a fine seed bed which is critical for germination, particularly with small seeded crops. The soil should have good water holding capacity to allow for uniform germination and continued vegetative growth. In Florida, the beds should be raised and shaped depending on rainfall. It is especially important to have uniform seedbeds because the seeds are often precision planted and uniform emergence and seedling development are required for optimum management. Proper irrigation is necessary to ensure growth during droughts. Drip irrigation is an effective way to deliver water to the crop without wetting vegetative plant parts thus reducing potential disease problems.

It is important that the fertility of the soil is improved when producing organically since chemical fertilizers can not be used. To ensure good fertility and fewer soil diseases, crop rotation, use of a cover crop, green manure crops, mulch, animal compost, and plant material compost can all be used. Floridas soils are generally sandy which provides good drainage and ease of tillage, yet nutrients are leached readily during heavy rains (Simone et al., 2001). Organic or natural fertilizers are generally made from bone meal, blood meal, horse, and chicken manure, mushroom compost, ash from sunflower seed hulls, and many other substances (White, 2001). Considerations and modifications must be made depending on the specific land selection and soil conditions. There are many commercial organic fertilizers available for organic crops with the major ones listed below. See Organic Vegetable Production at the UF/IFAS Extension publications Web site http://edis.ifas.ufl.edu/CV118 for a more extensive list.

- Composted manure (mushroom compost is mostly manure), or blood meal or feather meal, used to increase nitrogen content. Dried blood is also a useful nitrogen source when used with wood chip mulching, which is high in carbon, and low in nitrogen.

- Wood ashes, or potash, for increased potassium.

- Rock phosphate, often crushed rock that contains elevated levels of phosphate.

- Seaweed extract - not a fertilizer, but aids plant growth and resistance to pests and disease.

Inoculates used with bean and pea seeds provide beneficial fungi which work with the plant's roots to help them fix nitrogen from the air. Cover crops used between seasons as green manure may increase soil organic matter for the growing season (Simone et al., 2001).

\section{Planting Techniques}

Seeds are generally planted directly by drilling in the field or transplanting from a greenhouse grown seedling. These seeds should be organically produced and all transplants must be organically produced. The seeds must be planted in such a way that proper 
vegetative development occurs that will support fruit and seed development with proper spacing and depth in the bed. Vegetable seeds are greatly influenced by temperature at planting; pea, lettuce, radish, beets, onion, and spinach grow best at cool temperatures for optimum emergence. Other crops including squash, melon, tomato, pepper, and eggplant grow well at warmer soil temperatures. In general, the best germination temperature for all these crops is around $70^{\circ} \mathrm{F}$.

Row spacing and plant densities must allow for maximum plant development of the flower and unrestricted access to inflorescences for pollinators which will lead to proper fruit and seed set. Proper spacing will also allow for improved air movement reducing pathogens and space for harvest operations at the end of the season (McDonald et al., 1997).

Pollination of crops for seed is also affected by row spacing and planting densities; using larger spacing allows for better wind movement and more room for insect pollinators. Crops that are wind pollinated include sweet corn and spinach and those that are insect pollinated include carrot, onion, and broccoli.

\section{Weed, Insect, and Fungal Management}

Management of weeds and pests are critical to ensure that organically produced seeds have high yield and quality. It is common for insect pests after harvest of the primary host crop to move to another crop in a neighboring field. This is the case for the Lygus bug. It will feed on legume crops but once harvested, they will move to umbiliferous crops such as carrots. Other insects such as cabbage looper infest crops in the Brassica family and causes loss of vegetative parts effectively reducing seed yield and quality. Aphids are a problem, especially at harvest because they secrete "honeydew" on crops including tomato, squash, and pumpkin making harvesting difficult (McDonald et al., 1997). They also spread diseases, especially virus, which is difficult to control conventionally and even more challenging for an organic grower.

Because the seed crop is in the field for a longer period of time, there are more opportunities for multiple pathogens to interact with a single crop.
There are also cases where pathogens target the seed directly and affect the entire seed population. To control these pathogens organically is complex and requires proper growing conditions such as temperature and humidity to minimize the incidence of such pathogens as powdery mildew which thrives in high temperature and humidity. Seed producing fields should not be located near commercial vegetable fields. Eliminating weeds will help decrease insect habitats and pathogen spread from host plants likely to infect the seed crop.

There are effective pest control methods that control some of the major insect pests and diseases organically. Visit the following Web sites, http://www.extremelygreen.com/

pestcontrolguide.cfm and http://www.cals.ncsu.edu/sustainable/peet/IPM/ diseases/org_cert.html, to order products used in organic pest control and see Table 2 for an extensive list of suppliers.

\section{Biological Pest Control}

Another viable pest control method is through biological control. This practice is highly compatible with organic seed production, and it does not involve the use of chemicals. Biological control is defined as the decline of pest populations by natural enemies (Hoffman et al., 1993). Biological control utilizes three sources of natural enemies that can be used to control harmful pests and reduce the use of organic pesticides. The first group includes parasitoid insects, which lay their eggs inside another insect. An example of a parasitoid insect is the wasp, Aphidius colemani which lays its eggs in aphid adults. The wasp matures inside the aphid egg, killing the aphid and continuing the wasps life cycle. The second group of beneficial insects is predators, which eat other insects. A common predator is the lady beetle, which preys on insects and mites. The third group includes the weed feeders, which feed on weed populations. Insects such as a weevil, Hylobius transversovittatus feed on certain weeds including purple loosestrife. Pathogens such as fungi, viruses, bacteria, and nematodes are also capable of destroying weed populations and are called bioherbicides. Reducing weed populations is highly beneficial because often times during winter, pests 
live in weeds surrounding fields used for seed production (Hoffman et al., 1997). It is important to note that there are many beneficial insects that can be used to control a large number of pests. For more information on which beneficial insects to choose for a particular crop and sources of beneficial insects for biological control, contact the Cornell University Web site for Biological Control at http://www.nysaes.cornell.edu/ent/biocontrol and for North American Suppliers go to http://www.cdpr.ca.gov/docs/ipminov/ben_supp/ contents.htm.

\section{Harvesting, Threshing and Drying}

Vegetable seed crops are separated into two categories - those that produce wet-seeded fruits and those that are dry seeded. Wet-seeded crops include tomatoes, peppers, cucurbits and those that are dry seeded include the brassicas, legumes, and onions. Harvesting method depends on the type of seed being produced.

When harvesting dry-seeded crops, seed shattering must be prevented because seed harvest generally occurs after the crop reaches physiological maturity. To reduce shattering, the stalks of the plant need to be cut while still green and field dried allowing for uniform seed maturation. Once the seeds are mature, they can be machine or hand extracted. Observation may help to judge how the plant is maturing and for signs such as drying of florets or other plant parts. This can be complicated and it requires good knowledge of the crop but can lead to excellent seed quality, because the seeds will be harvested at peak maturity and size.

Determining when wet-seeded crops are mature for seed harvest depends primarily on fruit color. Peppers and tomatoes are harvested at full color because the percent germination is much higher in the mature red compared to the green fruit. In any case, wet-seeded fruits can be harvested, the pulp processed, and the seeds removed. The seeds must then be washed in water then dried either in the sun or by rotating in a large drum before oven drying. Modifications must be made with certain crops, such as melons, to remove the mucilaginous coating around the seed. When the seeds are removed from the pulp and outer coatings, they should be dried immediately to prevent fermentation (McDonald et al. 1997).

\section{Cleaning and Storage}

Once seeds are harvested, threshed, and extracted, they should be evaluated to determine if further cleaning is required to remove any debris such as dirt or plant parts. Small seeds such as carrots are sorted and separated using a debearder machine to remove unwanted outer seed parts. All seeds should be single units and all stored according to their individual temperature/humidity requirements. Seeds are best stored at $50 \%$ relative humidity at $50^{\circ} \mathrm{F}$ (Vavrina, 1995).

\section{Organic Seed Treatments: Pelleting Techniques}

The commercial seed industry often pellets seed, if the seed is irregularly shaped or small. Developments in seed technology have allowed for artificial seed pelleting materials to aid in regulation of water uptake by the seed which can influence germination rate. Seeds are pelleted with materials that coat with multiple layers of inert materials which shape and color the seed for better visualization during seeding. The drawback for organic growers is that the normal commercially available pelleted seeds have substances used to pellet that contain synthetic ingredients not permitted by the standards of the National Organic Program (NOP). According to the NOP Rules of the USDA National Organic Program, use of the USDA organic label or seal Subpart D describes the use of the USDA organic label or seal.

- For seed producers, much of the labeling information is not applicable.

- For example, products may be labeled as "100\% organic," "organic," or "made with organic ingredients." Since raw seed is a single composition product, it will either be " $100 \%$ organic" or not.

- Seed treatments must be approved by the National Organic Standards Board (NOSB) for use on organic seed. Prohibited substances (such as synthetic pesticides) may not be used on organic seed. 
- Pelleting and film coating materials must also be approved. The only time a seed product may not qualify as " $100 \%$ organic" is if a pelleting or film coating material contains a minor component(s) that is not organic. At that point a certifier would need to determine if it could be labeled "organic," indicating a product that contains (by weight or volume) not less than 95\% organically produced or processed agricultural products, or "made with organic ingredients," indicating made with at least $70 \%$ organically produced ingredients.

NATURECOAT $^{\circledR}$, a new technology developed by Harris Moran Seed Company (Modesto, CA), is an organic seed pelleting material that meets the NOP standards and is accepted by The Organic Materials Review Institute (OMRI). OMRI reviewed the raw materials and processes used to create these raw materials and pellets to verify that no material used in the process is synthetically derived.

According to The Harris Moran Company, the pellet is a light density, melting pellet with a smooth white surface and excellent uniformity. The materials form a pellet with a high porosity for increased oxygen availability. It has been thoroughly tested and commercialized for use on carrot seed and should be approved for lettuce and onion in the near future. Future work is planned to test NATURECOAT ${ }^{\circledR}$ on tomato, pepper, broccoli and cauliflower.

\section{Where to Find Organic Vegetable Seeds}

The Appropriate Technology Transfer for Rural Areas (ATTRA) has made available a list of contact information for suppliers of organic and untreated seed. They promote new seed suppliers that may be small but show innovation and promise for the organic seed industry. The Organic Materials Review Institute also publishes an extensive listing of organic seed suppliers that meet the OMRI standards. Seed suppliers are required to pay a fee to be listed. Seed suppliers will soon be required to provide a certificate in compliance with the Final Organic Rule instead of only being required to meet the suppliers local organic certifier requirements.
Listed below is a brief listing of contact information of some of the major seed suppliers that provide organic vegetable seed. For more information contact ATTRA online at http://attra.ncat.org/attra-pub/altseed.html or OMRI at http://www.omri.org.

\section{References}

George, R.T. 1999. Vegetable Seed Production Second Edition. Longman Press, Essex.

Hawthorn, L.R., Pollard, L. 1954. Vegetable and Flower Seed Production. The Blackiston Company, New York.

Hoffmann, M.P. and Frodsham, A.C. 1993. Natural Enemies of Vegetable Insect Pests, http://www.nysaes.cornell.edu/ent/biocontrol/ manual.html. Cooperative Extension, Cornell University, Ithaca, NY. http://www.nysaes.cornell.edu/ent/biocontrol/info/ biocont.html

Kirschenbaum, J. 2000. Saving Your Own Garden Seed. The Year Round Gardener. Terrestrial Seed Company. http://www.territorial-seed.com/news/aug00/ aug00.html

McDonald, M., Copeland, L. 1997. Seed Production Principles and Practices. International Thomson Publishing.

NATURECOAT - Harris Morans New "Organic" Seed Pellet for Carrots, Lettuce, Onions, \& Miscellaneous Species. 2004. Harris Moran. Modesto, CA. http://www.harrismoran.com/technology/ naturecoat.htm

Peet, M. 2002. Practices and Materials Permitted in Some Organic Certification Programs. http://www.cals.ncsu.edu/sustainable/peet/IPM/ diseases/org_cert.html

Simonne, E., Hochmuth, G. 2001. Soil and Fertilizer Management for Vegetable Production in Florida. UF/IFAS Coop. Ext. Serv., HS711. http://edis.ifas.ufl.edu/CV101 
Vavrina, C.S. 1995. Seed Quality and Seeding

Technology. UF/IFAS Coop. Ext. Serv., HS713.

http://edis.ifas.ufl.edu/CV103

Vegetable Seed Production. Department of

Horticulture and Crop Science. Ohio State

University.

http://www.ag.ohio-state.edu/ seedsci/vspo2.html

White, J.M 1995. Organic Vegetable Production.

UF/IFAS Coop. Ext. Serv., HS720.

http://edis.ifas.ufl.edu/CV118

\section{Further Information}

Cultural practices and sample costs for organic

vegetable production on the central coat of

California.

http://www.sarep.ucdavis.edu/pubs/costs/96/vege.htm 
Table 1. Seed spacing recommendations for vegetable seed production.

\begin{tabular}{||l|c|c||}
\hline \hline Family & Crop & Spacing \\
\hline Solanaceae & Tomato & $9-12$ inches \\
& Eggplant & $18-24$ inches \\
& Pepper & $14-18$ inches \\
\hline Cucurbitaceae & Cucumber & 12 inches \\
& Squash & $24-36$ inches \\
& Watermelon & $24-36$ inches \\
\hline Compositaceae & Head Lettuce & $10-12$ inches \\
& Loose Leaf & $6-8$ inches \\
\hline Brassicaceae & Broccoli & $18-24$ inches \\
& Cauliflower & $18-24$ inches \\
\hline \hline
\end{tabular}

Table 2. Products and organic methods for pest control.

\begin{tabular}{||l|l|l|l||}
\hline \hline Product & \multicolumn{1}{|c|}{ Problem } & \multicolumn{1}{c|}{ Material } & \multicolumn{1}{c||}{ Comments } \\
\hline Azatin EC & $\begin{array}{l}\text { Whiteflies,leafminer,fungus } \\
\text { gnats, armyworms, aphids, } \\
\text { thrips, loopers, cutworms }\end{array}$ & $\begin{array}{l}\text { Botanical insecticide of } \\
\text { Neem tree }\end{array}$ & $\begin{array}{l}\text { Controls insects by disrupting insect } \\
\text { molting by antagonizing the insect } \\
\text { hormone ecdysone }\end{array}$ \\
\hline $\begin{array}{l}\text { Bacillus } \\
\text { thuringiens }\end{array}$ & $\begin{array}{l}\text { Caterpillars, cabbageworms, } \\
\text { fruitworms, hornworms }\end{array}$ & $\begin{array}{l}\text { Bacterial spore extract } \\
\text { toxic to caterpillars }\end{array}$ & $\begin{array}{l}\text { After ingesting Bt, caterpillars stop } \\
\text { feeding (usually within an hour) and die } \\
\text { within a few days }\end{array}$ \\
\hline $\begin{array}{l}\text { Insecticidal } \\
\text { Soaps }\end{array}$ & $\begin{array}{l}\text { Soft-bodied pests such as } \\
\text { whiteflies, aphids, and spider } \\
\text { mites }\end{array}$ & $\begin{array}{l}\text { Kills susceptible insects } \\
\text { by washing away the } \\
\text { protective coating on the } \\
\text { surface of the insect } \\
\text { disrupts normal } \\
\text { membrane function }\end{array}$ & $\begin{array}{l}\text { Commercial brands are available, and } \\
\text { are safe to use with little no damage to } \\
\text { beneficials }\end{array}$ \\
\hline Pyretherin & $\begin{array}{l}\text { Beetles, caterpillars, various } \\
\text { sucking insects }\end{array}$ & $\begin{array}{l}\text { Causes a rapid } \\
\text { knockdown and paralysis } \\
\text { of most insects }\end{array}$ & $\begin{array}{l}\text { Insects may recover unless the product } \\
\text { is mixed with a synergist or other } \\
\text { toxicant }\end{array}$ \\
\hline Rotetone & $\begin{array}{l}\text { Aphids, certain beetles, and } \\
\text { caterpillars }\end{array}$ & $\begin{array}{l}\text { Stomach poison, insects } \\
\text { short residual activity, } \\
\text { losing its effectiveness } \\
\text { within a week }\end{array}$ & $\begin{array}{l}\text { Insecticide harmless to plants highly } \\
\text { toxic to fish and many insects, } \\
\text { moderately toxic to mammals, and } \\
\text { leaves no harmful residues on } \\
\text { vegetables }\end{array}$ \\
\hline Copper & $\begin{array}{l}\text { Leaf spot, anthracnose, } \\
\text { mildew, blight and black rot } \\
\text { siseases }\end{array}$ & $\begin{array}{l}\text { Disrupts electron } \\
\text { transport along the } \\
\text { cytochromes }\end{array}$ & $\begin{array}{l}\text { Copper sulfate, alone or mixed with } \\
\text { hydrated lime (Bordeaux mixture) }\end{array}$ \\
\hline of proteins and enzymes
\end{tabular}


Table 3. Listing of organic, open pollinated, and heirloom seed suppliers.

\begin{tabular}{|c|c|c|}
\hline $\begin{array}{l}\text { Seed Company } \\
\text { Certified Organic }\end{array}$ & $\begin{array}{l}\text { Products } \\
\text { Seed Suppliers }\end{array}$ & Contact Information \\
\hline $\begin{array}{l}\text { Fedco Seeds } \\
\text { P.O. Box } 520 \\
\text { Waterville, ME } 04903\end{array}$ & $\begin{array}{l}\text { Certified Organic vegetable, seed } \\
\text { potato, tubers and supplies for organic } \\
\text { growers }\end{array}$ & $\begin{array}{l}\text { 207-873-7333 } \\
\text { http://www.fedcoseeds.com }\end{array}$ \\
\hline $\begin{array}{l}\text { Harris Seeds } \\
\text { P.O. Box } 24966 \\
\text { Rochester, NY } 14624\end{array}$ & $\begin{array}{l}\text { Selected organic vegetable seeds } 1 \mathrm{oz} \\
\text { packets and organic pelleting }\end{array}$ & $\begin{array}{l}\text { 800-544-7938 } \\
\text { http://www.harrisseeds.com }\end{array}$ \\
\hline $\begin{array}{l}\text { High Mowing Seeds } \\
813 \text { Brook Road } \\
\text { Walcott, VT } 05680\end{array}$ & $\begin{array}{l}\text { Organic and Open-pollinated } \\
\text { vegetable, flower, herb seeds for } \\
\text { Northeast }\end{array}$ & $\begin{array}{l}\text { 802-888-1800 } \\
\text { http://highmowingseeds.com }\end{array}$ \\
\hline $\begin{array}{l}\text { Johnnys Selected Seeds } \\
\text { Foss Hill Road } \\
\text { Albion, ME } 04910\end{array}$ & $\begin{array}{l}\text { Wholesale \& Retail certified organic } \\
\text { vegetable, flower, herb seeds \& } \\
\text { potting mix }\end{array}$ & $\begin{array}{l}\text { 207-437-4301 } \\
\text { http://www.johnnyseeds.com }\end{array}$ \\
\hline $\begin{array}{l}\text { Moorhill Farm and Greenhouses } \\
\text { Rte. } 1 \text { Box } 5510 \\
\text { Mt. Vernon. ME } 04352\end{array}$ & $\begin{array}{l}\text { Wholesale organic seedlings \& retail } \\
\text { herb and vegetable seed }\end{array}$ & $207-293-2268$ \\
\hline $\begin{array}{l}\text { Peaceful Valley Farm Supply } \\
\text { P.O. Box } 2209 \\
\text { Grass Valley, CA } 95945\end{array}$ & $\begin{array}{l}\text { Wholesale\& Retail Bulk Seed certified } \\
\text { by CCOF \& carries Seeds of change } \\
\text { packets }\end{array}$ & $\begin{array}{l}\text { 888-784-1722 } \\
\text { http://www.groworganic.com }\end{array}$ \\
\hline $\begin{array}{l}\text { Rebeccas Garden } \\
10601 \text { Vista Road } \\
\text { Columbia, MO } 21044\end{array}$ & Certified organic tomato seed only & $\begin{array}{l}\text { 401-531-5144 } \\
\text { rebsorggarden@aol.com }\end{array}$ \\
\hline $\begin{array}{l}\text { Seeds of Change } \\
\text { P.O. Box } 15700 \\
\text { Santa Fe, NM } 87592\end{array}$ & $\begin{array}{l}\text { Certified Oregon Tilth organic } \\
\text { vegetable, flower and herb seeds }\end{array}$ & $\begin{array}{l}\text { 888-762-7333 } \\
\text { http://seedsofchange.com }\end{array}$ \\
\hline $\begin{array}{l}\text { SemTec } \\
\text { P.O. Box } 418 \\
\text { Center, CO } 81125\end{array}$ & Certified organic seed potato only & $\begin{array}{l}\text { 719-754-2946 } \\
\text { http://www.semtecseed.com }\end{array}$ \\
\hline $\begin{array}{l}\text { Southern Oregon Organics } \\
1130 \text { Tetherow Road } \\
\text { Williams, OR } 97544\end{array}$ & $\begin{array}{l}\text { Producers of certified organic seed } \\
\text { primarily for Pacific Northwest }\end{array}$ & $\begin{array}{l}541-846-7173 \\
888-709-7333 \\
\text { http://organicseed.com/ }\end{array}$ \\
\hline $\begin{array}{l}\text { Stokes Seeds } \\
\text { P.O. Box } 548 \\
\text { Buffalo, NY } 14240-0548\end{array}$ & $\begin{array}{l}\text { Certain organic vegetable seeds } \\
\text { availble, OP, untreated seeds }\end{array}$ & $\begin{array}{l}\text { 716-695-6980 } \\
\text { http://www.stokesseeds.com }\end{array}$ \\
\hline $\begin{array}{l}\text { Terretorial Seed Co. } \\
\text { P.O. Box } 158 \\
\text { Cottage Grove, OR } 97424\end{array}$ & Organic vegetable seed supplier & $\begin{array}{l}\text { 541-942-9547 } \\
\text { http://www.terretorial-seed.com }\end{array}$ \\
\hline $\begin{array}{l}\text { Tinmouth Channel Farm } \\
\text { Town Road } 19 \\
\text { Wallingford Box } 428 \text { B } \\
\text { Tinmouth, VT } 05773\end{array}$ & $\begin{array}{l}\text { Certified by OCIA over } 1000 \text { organic } \\
\text { herbs }\end{array}$ & $802-446-2812$ \\
\hline $\begin{array}{l}\text { Wood Prairie Farm } \\
49 \text { Kinney Road } \\
\text { Bridewater, ME } 04734\end{array}$ & Organic Potato Seeds Only & $800-829-9765$ \\
\hline Open Pollinated & Heirloom Seed Suppliers & (Not Organic Unless Specified) \\
\hline $\begin{array}{l}\text { Baker Creek Heirloom Seeds } \\
2278 \text { Baker Creek Rd } \\
\text { Mansfield, MO } 65704\end{array}$ & $\begin{array}{l}\text { Especially large selection heirloom } \\
\text { eggplant, melon, watermelon \& squash }\end{array}$ & $\begin{array}{l}\text { 417-924-8917 } \\
\text { http://www.rareseeds.com }\end{array}$ \\
\hline
\end{tabular}


Table 3. Listing of organic, open pollinated, and heirloom seed suppliers.

\begin{tabular}{|c|c|c|}
\hline $\begin{array}{l}\text { Seed Company } \\
\text { Certified Organic }\end{array}$ & $\begin{array}{c}\text { Products } \\
\text { Seed Suppliers }\end{array}$ & Contact Information \\
\hline $\begin{array}{l}\text { Butterbrooke Farm } \\
78 \text { Barry Road } \\
\text { Oxford, CT } 06478\end{array}$ & $\begin{array}{l}\text { Non-hybrid hardy vegetable strains } \\
\text { raised by cooperating farms }\end{array}$ & 203-888-2000 \\
\hline $\begin{array}{l}\text { Eastern Native Seed Conservancy } \\
\text { P.O. Box } 451 \\
\text { Great Barrington, MA } 01230\end{array}$ & Non-profit Seed Exchange & $413-229-8316$ \\
\hline $\begin{array}{l}\text { Eden Organic Nursery Services } \\
\text { Inc. } \\
\text { P.O. Box } 4604 \\
\text { Hallandale, FL } 33008\end{array}$ & $\begin{array}{l}\text { Open Pollinated, Hybrid pepper seed } \\
\text { \& organic tobacco, garden supplies }\end{array}$ & $\begin{array}{l}\text { 954-455-0229 } \\
\text { http://www.eonseed.com }\end{array}$ \\
\hline $\begin{array}{l}\text { Heirloom Seeds } \\
\text { P.O. Box } 245 \text { W. } \\
\text { Elizabeth, PA } 15088-0245\end{array}$ & Heirloom vegetable, fruit, herb seed & $\begin{array}{l}\text { 417-384-0853 } \\
\text { http://heirloomseeds.com }\end{array}$ \\
\hline $\begin{array}{l}\text { Henry Fields Seed \& Nursery } \\
415 \text { N. Burnett } \\
\text { Shenandoah, IA } 51602\end{array}$ & $\begin{array}{l}\text { Good source for heirloom varieties of } \\
\text { vegetables }\end{array}$ & \\
\hline $\begin{array}{l}\text { John Scheepers Kitchen Garden } \\
\text { Seeds } \\
23 \text { Tulip Drive } \\
\text { Bantam, CT } 06570\end{array}$ & $\begin{array}{l}\text { New Company } 02 \\
\text { Vegetables and Herbs }\end{array}$ & $\begin{array}{l}\text { 860-567-6086 } \\
\text { http://www.kitchengardenseeds.com }\end{array}$ \\
\hline $\begin{array}{l}\text { New England Seed Company } \\
3580 \text { Main Street Bldg. } 10 \\
\text { Hartford, CT } 06120\end{array}$ & $\begin{array}{l}\text { Oldest Seed Co. in US large heirloom } \\
\text { vegetable seed collection }\end{array}$ & $\begin{array}{l}\text { 860-724-1240 } \\
\text { http://www.neseed.com }\end{array}$ \\
\hline $\begin{array}{l}\text { Pinetree Garden Seeds } \\
\text { PO Box } 300 \\
\text { New Gloucester, ME } 04260\end{array}$ & $\begin{array}{l}\text { Specializes in seed packets sized for } \\
\text { home gardeners }\end{array}$ & http://www.superseeds.com \\
\hline $\begin{array}{l}\text { The Cooks Garden } \\
\text { P.O. Box } 5010 \\
\text { Hodges, SC } 29653\end{array}$ & $\begin{array}{l}\text { Open-pollinated vegetable, flower, } \\
\text { herb seeds }\end{array}$ & $\begin{array}{l}\text { 800-457-9705 } \\
\text { http://www.cooksgarden.com }\end{array}$ \\
\hline $\begin{array}{l}\text { Thompson and Morgan } \\
\text { P.O. Box } 1308 \\
\text { Jackson, NJ } 08527\end{array}$ & $\begin{array}{l}\text { Retail \& Wholesale open-pollinated } \\
\text { vegetable, herb and flower seed }\end{array}$ & $\begin{array}{l}\text { 800-274-7333 } \\
\text { http://www.thompson-morgan.com }\end{array}$ \\
\hline $\begin{array}{l}\text { Seed Savers Exchange } \\
3067 \text { N. Winne Road } \\
\text { Decorah, IA } 52101\end{array}$ & $\begin{array}{l}\text { Retail Branch of largest US seed } \\
\text { exchange }\end{array}$ & $\begin{array}{l}\text { 319-382-5990 } \\
\text { http://www.seedsavers.org }\end{array}$ \\
\hline $\begin{array}{l}\text { Seeds for the South } \\
410 \text { Whaley Pond Road } \\
\text { Graniteville, SC } 29829\end{array}$ & Heirloom seeds for the Southern states & http://www.seedsforthesouth.com \\
\hline $\begin{array}{l}\text { Southern Exposure Seeds } \\
\text { Exchange } \\
\text { P.O. Box } 460 \\
\text { Mineral, VA } 23117\end{array}$ & Open-pollinated vegetables and herbs & $\begin{array}{l}\text { 540-894-9480 } \\
\text { http://www.southernexposure.com }\end{array}$ \\
\hline $\begin{array}{l}\text { Tomato Growers Supply Co. } \\
\text { P.O. Box } 2237 \\
\text { Fort Myers, FL } 33902\end{array}$ & Heirloom tomato and pepper seeds & $\begin{array}{l}\text { 888-478-7333 } \\
\text { http://www.tomatogrowers.com }\end{array}$ \\
\hline
\end{tabular}

